Original Research Paper

\title{
FAKTOR-FAKTOR YANG BERHUBUNGAN DENGAN KETIDAKPATUHAN MEMBERIKAN IMUNISASI DI PUSKESMAS PEMBANTU DESA MANINILI UTARA
}

\author{
${ }^{1 *}$ Hasnidar, ${ }^{2}$ Nurul Rahma Danni \\ ${ }^{1}$ Universitas Tadulako \\ ${ }^{2}$ STIKes Widya Nusantara Palu
}

\begin{tabular}{l} 
Email Corresponding: \\
needare@ rocketmail.com \\
Page : $134-140$ \\
\hline
\end{tabular}

Kata Kunci :

Pengetahuan,

Sikap,

Ketidakpatuhan,

Imunisasi

Keywords:

Knowledge,

Attitude,

Disobedience,

Immunization

\begin{abstract}
ABSTRAK
Imunisasi adalah upaya untuk meningkatkan kekebalan tubuh manusia baik pasif maupun aktif, agar ketika tubuh terinfeksi penyakit maka tidak mudah untuk menjadi sakit. Tujuan penelitian ini adalah untuk mengetahui apa-apa saja yang berhubungan dengan ketidakpatuhan orang tua dalam memberikan imunisasi lengkap di wilayah kerja puskesmas pembantu desa maninili utara. Jenis penelitian adalah kuantitatif, survei analitik dengan menggunakan pendekatan Cross Sectional. Populasi dalam penelitian ini adalah 41 balita Pengambilan sampel dalam penelitian ini menggunakan tehnik total sampling (tekhnik sampel jenuh). Uji yang digunakan untuk analisis univariat adalah presentase dan analisis bivariat yaitu uji Chi-square. Hasil penelitian pengetahuan $(\mathrm{p}=0.04)$, sikap $(\mathrm{p}=0.04)$, dukungan keluarga $(\mathrm{p}=0.01)$, jarak $(\mathrm{p}=0.44)$, dukungan petugas kesehatan $(\mathrm{p}=0.34)$. Kesimpulan ada hubungan antara pengetahuan, sikap, dan dukungan keluarga, serta tidak ada hubungan antara jarak dan dukungan petugas kesehatan terhadap pemberian imunisasi lengkap di wilayah kerja Puskesmas Pembantu desa Maninili Utara. Diharapakan hasil penelitian ini menjadi bahan atau masukan untuk masyarakat desa maninili utara dalam melakukan pemberian imunisasi.
\end{abstract}

ABSTRACT
Immunisation is the effort to increase the human immunity both passive and
active type for illness prevention during infectious time. The aims of this
research to obtain the correlation factors toward unobedience of parents in
complete immunisation administered in Sub PHC North Maninili Village region.
This is quantitative research with analyses survey by used the Cross Sectional
approached. The total of population was 14 babies under 5 years old and
sampling taken by total sampling technique. Univariate analyses test used for
precentage and bivariate analyses for Chi-square test. The result of research for
knowledge ( $p=0.04)$, attitude ( $p=0.04)$, families support ( $p=0.01)$, distance
(p=0.04), health worker's support ( $p=0.34)$. Conclusion that have correlation
between knowledge, attitude and families support, but have no correlation
betweeen distance and health worker support toward complete immunisation
administered in Sub PHC North Maninili Village region. Expectation of this
research result could become a reference for community in North Maninili
Village in performing of immunisation administered.

Published by:

Tadulako University,

Managed by Faculty of Medicine.

Email: healthytadulako@gmail.com

Phone (WA): +6285242303103

Address:

Jalan Soekarno Hatta Km. 9. City of

Palu, Central Sulawesi, Indonesia

\section{PENDAHULUAN}

Imunisasi merupakan cara untuk menimbulkan/meningkatkan sistem imun seseorang secara aktif terhadap suatu penyakit, sehingga bila suatu saat terpajan dengan penyakit tersebut tidak akan sakit atau hanya mengalami sakit ringan ${ }^{1}$.

WHO, mengungkapkan setiap tahunnya ada kurang lebih 1,5 juta anak yang terkena penyakit menular. Sekitar, 20 juta anak belum mendapatkan imunisasi lengkap, juga masih ada anak-anak yang belum diberikan imunisasi lengkap ${ }^{2}$. Pemerintah selalu mengupayakan agar anak-anak di Indonesia mendapatkan imunisasi lengkap secara menyuluruh.sebab, masih banyak orang tua yang belum mengetahui serta memahami pentingnya memberikan imunisasi lengkap kepada 
anaknya, banyaknya berita buruk perihal efek dari pemberian imunisasi membuat orang tua tidak mau memberikan imunisasi pada anaknya ${ }^{1}$.

Negara berkembang termasuk Indonesia masih banyak terdapat penyakit yang di sebabkan infeksi. Di Indonesia sekitar 1,7 juta atau $15 \%$ terjadi kematian pada anak dan balita disebabkan oleh penyakit yang dapat dicegah oleh imunisasi yaitus seperti TBC, difteri, pertusis, campak, tetanus, polio dan Hepatitis B.1 Angka kematian neonatal di Provinsi Sulawesi Tengah sebanyak 445 kasus dengan jumlah kematian tertinggi terdapat di kabupaten Parigi Moutong sebanyak 69 kasus kemudian kabupaten ToliToli 53 kasus dan kabupaten Donggala 46 kasus sedangkan angka kematian neonatal terendah sebanyak 8 kasus berada di Kota Palu ${ }^{3}$.

Tingginya kasus penyakit yang dapat dicegah dengan pemberian imunisasi lengkap tidak lepas dari peranan orang tua. Kurangnya pemahaman terhadap pemberian imunisasi serta efek samping dari pemberian imunisasi menjadi salah satu alasan ketidakpatuhan dalam memberikan imunisasi pada anaknya. Ketidakpatuhan adalah salah satu yang menjadi kendala dalam terpenuhinya target imunisasi. Sehingga, diperlukan kepatuhan orang tua dalam memberikan imunisasi secara lengkap agar dapat menekan angka kasus penyakit akibat infeksi ${ }^{4}$.

Studi pendahuluan yang dilakukan oleh peneliti pada tanggal 16 maret 2020 dengan melakukan wawancara pada petugas puskesmas pembantu Desa Maninili Utara, bahwa masih banyak orang tua yang tidak memberikan imunisasi kepada anaknya. Data yang didapatkan ada sebanyak 66 balita yang belum memiliki imunisasi lengkap. Petugas kesehatan juga menjelaskan bahwa banyak orang tua yang tidak ingin memberikan imunisasi kepada anaknya karna akan membuat anak mereka jatuh sakit, rewel setelah di imunisasi, dan masih banyak berbagai alasan orang tua tidak patuh untuk memberikan imunisasi pada anaknya. Wawancara yang peneliti lakukan kepada beberapa orang tua terkait alasan tidak ingin memberikan imunisasi kepada anak, dikarenakan mereka berasumsi bahwa memberikan imunisasihanya membuat anak mereka jatuh sakit, ada juga yang merasa tidak memiliki waktu untuk memberikan munisasi karena sedang bekerja, serta beberapa berasumsi bahwa orang tua mereka terdahulu juga tidak mendapatkan imunisasi tetapi tidak terkena penyakit apa-apa. Sehingga ,mereka juga enggan memberikan imunisasi kepada anaknya. Meskipun demikian berbagai cara dilakukan petugas kesehatan bekerja sama dengan aparat Desa Maninili Utara agar orang tua mau memberikan imunisasi pada anaknya.

Berdasarkan hasil studi diatas peneliti merasa tetarik untuk melakukan penelitian dengan judul “ Faktor-Faktor yang Berhubungan dengan Ketidakpatuhan Orang Tua dalam Memberikan Imunisasi Lengkap di Wilayah Kerja Puskesmas Pembantu Desa Maninili Utara"

\section{BAHAN DAN CARA}

Jenis penelitian yang digunakan adalah kuantitatif dengan desain cross sectional. Penelitian ini dilaksanakan di wilayah kerja Puskesmas Pembantu Desa Maninili Utara. Penelitian ini dilaksanakan pada tanggal 18 maret - 24 juni 2020.

Pada penelitian ini, yang menjadi populasinya yaitu orang tua yang memiliki balita usia 1-5 tahun di Desa Maninili Utara yang berjumlah 41 orang balita.

Pengambilan sampel dalam penelitian ini menggunakan tehnik total sampling, dengan menggunakan uji chi square (fisher exact).

\section{HASIL}

\section{Analisis Univariat}


Tabel 1. Distribusi frekuensi karakteristik responden di Desa Maninili Utara

\begin{tabular}{lll}
\hline Varibel & $\mathbf{f}$ & $\mathbf{\%}$ \\
\hline Umur & & \\
Dewasa awal (26-35) & 21 & 51.2 \\
Remaja akhir (17-25) & 20 & 48.8 \\
\hline Total & $\mathbf{4 1}$ & $\mathbf{1 0 0}$ \\
\hline $\begin{array}{l}\text { Pendidikan } \\
\text { Rendah ( tidak tamat }\end{array}$ & 41 & 100 \\
SD, SD dan SMP) & & \\
\hline Total & $\mathbf{4 1}$ & $\mathbf{1 0 0}$ \\
\hline $\begin{array}{l}\text { Pekerjaan } \\
\text { Bekerja } \\
\text { Tidak Bekerja }\end{array}$ & 35 & 14.6 \\
\hline Total & $\mathbf{4 1}$ & $\mathbf{1 0 0}$ \\
\hline Status Kelengkapan & & \\
Tidak Diberikan & 8 & 19.5 \\
Tidak Lengkap & 33 & 80.5 \\
\hline Total & $\mathbf{4 1}$ & $\mathbf{1 0 0}$
\end{tabular}

Sumber: Data Primer 2020
Tabel 2. Distribusi frekuensi variabel independen faktor-faktor ketidakpatuhan

\begin{tabular}{llc}
\hline Variabel & f & \% \\
\hline Pengetahuan & & \\
Baik & 20 & 48.8 \\
Kurang Baik & 21 & 51.2 \\
\hline Total & $\mathbf{4 1}$ & $\mathbf{1 0 0}$ \\
\hline Sikap & & \\
Positif & 20 & 48.8 \\
Negatif & 21 & 51.2 \\
\hline Total & $\mathbf{4 1}$ & $\mathbf{1 0 0}$ \\
\hline Dukungan Keluarga & & \\
Baik & 14 & 34.1 \\
Kurang Baik & 27 & 65.9 \\
\hline Total & $\mathbf{4 1}$ & $\mathbf{1 0 0}$ \\
\hline Jarak Tempat Pelayanan & & \\
Terjangkau & 25 & 61.0 \\
Tidak Terjangkau & 16 & 39.0 \\
\hline Total & $\mathbf{4 1}$ & $\mathbf{1 0 0}$ \\
\hline Dukungan Petugas Kesehatan & & \\
Baik & 32 & 78.0 \\
Kurang Baik & 9 & 22.0 \\
\hline Total & $\mathbf{4 1}$ & $\mathbf{1 0 0}$ \\
\hline Sumber: Data Primer 2020 & & \\
\hline & & \\
\hline & &
\end{tabular}

\section{Analisis Bivariat}

Tabel 3. Distribusi hubungan faktor-faktor terhadap ketidakpatuhan pemberian imunisasi

\begin{tabular}{|c|c|c|c|c|c|c|c|}
\hline \multicolumn{8}{|c|}{ Pemberian Imunisasi } \\
\hline \multirow{2}{*}{ Variable } & \multicolumn{2}{|c|}{ Tidak Diberikan } & \multicolumn{2}{|c|}{ Tidak Lengkap } & \multicolumn{2}{|c|}{ Total } & \multirow{2}{*}{ P value } \\
\hline & $\mathbf{N}$ & $\%$ & $\mathbf{N}$ & $\%$ & $\mathbf{N}$ & $\%$ & \\
\hline \multicolumn{8}{|l|}{ Pengetahuan } \\
\hline Baik & 1 & 12.5 & 19 & 57.6 & 20 & 48.8 & \multirow{3}{*}{0.045} \\
\hline Kurang Baik & 7 & 87.5 & 14 & 42.4 & 21 & 51.2 & \\
\hline Total & 8 & 100 & 33 & 100 & 41 & 100 & \\
\hline \multicolumn{8}{|l|}{ Sikap } \\
\hline Positif & 1 & 12.5 & 19 & 57.64 & 20 & 48.8 & \multirow{3}{*}{0.045} \\
\hline Negatif & 7 & 87.5 & 14 & 42.4 & 21 & 51.2 & \\
\hline Total & 8 & 100 & 33 & 100 & 41 & 100 & \\
\hline \multicolumn{8}{|l|}{ Dukungan Keluarga } \\
\hline Baik & 6 & 75.0 & 8 & 24.2 & 14 & 34.165 & \multirow{3}{*}{0.012} \\
\hline Kurang Baik & 2 & 25.0 & 25 & 75.8 & 27 & .9 & \\
\hline Total & 8 & 100 & 33 & 100 & 41 & 100 & \\
\hline \multicolumn{8}{|c|}{ Jarak tempat pelayanan } \\
\hline Terjangkau & 6 & 75.0 & 19 & 57.6 & 25 & 61.0 & \multirow{3}{*}{0.448} \\
\hline Tidak Terjangkau & 2 & 25.5 & 14 & 42.4 & 16 & 39.0 & \\
\hline Total & 8 & 100 & 33 & 100 & 41 & 100 & \\
\hline \multicolumn{8}{|l|}{ Dukungan Petugas } \\
\hline Baik & 5 & 62.5 & 27 & 81.8 & 32 & 18.0 & \multirow{3}{*}{0.342} \\
\hline Kurang Baik & 3 & 37.5 & 6 & 18.2 & 9 & 22.0 & \\
\hline Total & 8 & 100 & 33 & 100 & 41 & 100 & \\
\hline
\end{tabular}

Sumber: Data Primer 2020 


\section{PEMBAHASAN}

\section{Analisa Univariat}

\section{Pengetahuan}

Berdasarkan hasil penelitian pada tabel 2. Menunjukkan bahwa masih banyak responden yang kurang mengetahui tentang imunisasi, responden yang memiliki pengetahuan kurang baik sebanyak 21 (51.2\%) dan responden yang memiliki pengetahuan baik sebanyak 20 (48.8\%) responden. Dilihat dari hasil penelitian ini tentang pengetahuan responden masih kurang mengetahui tentang imun isasi dasar serta pentingnya memberikan imunisasi pada anaknya. Dalam hal ini dapat di lihat dari jawaban yang diberikan responden pada saat mengisi kuesioner, masih banyak responden yang kurang mengetahui pengertian serta jenis dan cara pemberian imunisasi. Responden yang memiliki pengetahuan yang cukup tetapi masih tidak memberikan dan melengkapi status imunisasi hal ini dikarenakan masih banyak responden yang menganggap bahwa imunisasi tidak penting untuk anaknya hanya membuat anaknya rewel dan merepotkan.

\section{Sikap}

Berdasarkan hasil penelitian pada tabel. 2 menunjukkan bahwa sebagian responden memiliki sikap yang negatif sebanyak 21 ( $51.2 \%$ ) responden dalam pemberian imunisasi dasar lengkap kepada anaknya, dan 20 ( 48.8) memiliki sikap yang positif tetapi masih belum memberikan dan melengkapi imunisasi anaknya.

Responden yang memiliki sikap positif tetapi masih juga belum memberikan atau melengkapi imunisasi anaknya karena mereka menganggap bahwa informasi tentang imunisasi hanya merupakan hal biasa bukan hal yang penting untuk dilakukan. Kemudian dari segi pengetahuan mereka masih menganggap bahwa imunisasi itu hanya merupakan vitamin yang tidak terlalu berpengaruh terhadap mereka dan anaknya, di tambabah lagi pendidikan responden yang hamper seluruhnya tamatan SD sehingga sikap mereka untuk mengimunisasikan anaknya masih dipengaruhi oleh pola pikir pada masamasa dulu orang tua mereka yang terlebih dahulu belum menerima adanya imunisasi ini.

\section{Dukungan Keluarga}

Berdasarkan hasil dari penelitian pada tabel 2 menunjukkan bahwa hanya sebagian kecil responden yang mendapat dukungan dari keluarga perihal pemberian imunisasi dasar lengkap pada anaknya yakni 14 ( $34.1 \%$ ) responden tetapi masih belum memberikan dan melengkapi imunisasi dasar anaknya, hal ini dikarenakan karena kesibukan orang tua yang mana sebagian besar pekerjaan ibu adalah irt sebanyak 35 ( $85.4 \%$ ) responden namun ibu-ibu tersebut masih memiliki kesibukan sehari-hari yaitu pergi berkebun atau menjual ikan di halaman rumah untuk membantu suami atau keluarga untuk mencukupi kebutuhan sehari-hari.sedangkan responden yang mendapat dukungan keluarga kurang baik sebanyak 27 ( $65.9 \%$ ) hal ini di lihat dari responden tidak mendapatkan pujian ketika memberikan imunisasi kepada anaknya, juga karena keluarga kurang memperhatikan status imunisasi dari anak responden atau bersikap acuh.

\section{Jarak tempat pelayanan}

Berdasarkan hasil penelitian pada tabel 2 menunjukkan bahwa dari 41 responden sebanyak 25 ( $61.0 \%$ ) responden dapat menjangkau tempat pelayanan imunisasi dengan mudah tetapi tidak melengkapi status imunisasi anaknya sebanyak 19 orang,lebih banyak dibanding yang tidak memberikan imunisasi kepada anaknya sebanyak 6 responden hal ini dapat dilihat dari tempat tinggal orang tua yang tidak jauh dan tidak membutuhkan transportasi yang mahal untuk pergi ke tempat pelayanan hanya saja kesibukan orang tua serta ke rewelan anaknya 
ketika hendak di bawa ke tempat pelayanan imunisasi sehingga orang tua merasa kerepotan ketika akan membawa anaknya untuk di imunisasi.

\section{Dukungan petugas kesehatan}

Berdasarkan hasil penelitian pada tabel 2 menunjukkan bahwa petugas kesehatan dalam penelitian ini memiliki dukungan yang tinggi kepada orang tua karena sebanyak 32 responden mendapatkan dukungan yang baik dari petugas kesehatan yaitu berupa pemberian informasi kesehatan yang berkaitan dengan pentingnya imunisasi dasar, dukungan petugas kesehatan terhadap responden yang tinggi akan tetapi masih banyak responden yang masih belum memberikan dan melengkapi status imunisasi anaknya di karenakan pola pikir orang tua yang kurang baik dan merasa imunisasi ini bukanlah hal yang penting untuk anaknya sehingga, meskipun petugas kesehatan selalu mengingatkan dan memberikan informasi terkait imunisasi kepada orang tua mereka hanya mendengarkan saja tidak langsung mematuhi arahan untuk memberikan imunisasi yang lengkap kepada anak-anaknya.

\section{Analisa Bivariat}

\section{Hubungan pengetahuan dengan ketidakpatuhan pemberian imunisasi}

Berdasarkan hasil penelitian ini analisa bivariat yang menggunakan uji chi-square ( Fisher exact ) pada tabel 3 memperlihatkan hasil $\mathrm{p}=0.02$ yang artinya $\mathrm{H} 0$ ditolak berarti terdapat hubungan antara pengetahuan orang tua terhadap ketidakpatuhan memberikan imunisasi lengkap. Penelitian ini ketika melakukan wawancara kepada responden bahwa masih banyak responden yang kurang memahami pentingnya imunisasi serta masih belum menerima manfaat yang didapatkan ketika memberi imunisasi bagi kesehatan anaknya. Hal ini dikarenakan pola pikir yang masih berpandangan pada masa lampau ketika orang tua terdahulu mereka tidak mendapatkan imunisasi namun tetap merasa sehat dan tidak terkena penyakit seperti yang dapat di cegah oleh pemberian imunisasi. Penelitian ini juga sejalan dengan penelitian yang dilakukan Siti Umaroh bahwa anak-anak yang belum mendapatkan imunisasi dasar sebagian besar memiliki ibu dengan pengetahuan yang kurang tentang imunisasi ${ }^{5}$.

\section{Hubungan sikap dengan ketidakpatuhan orang tua memberikan imunisasi}

Berdasarkan hasil penelitian ini analisa bivariat yang menggunakan uji chi-square (Fisher exact) pada tabel 3 didapatkan $\mathrm{p}=0.02$ atau $\mathrm{p}=<0.05$ yang artinya H0 ditolak atau terdapat hubungan anatara sikap dengan ketidakpatuhan ibu memberikan imunisasi. dalam penelitian ini responden yang memiliki sikap negatif yang tidak memberikan dan melengkapi imunisasi anaknya dipengaruhi oleh kurangnya pemahaman yang mendorong keinginan atau motivasi untuk mengimunisasikan anaknya secara lengkap. Dari hasil wawancara yang peneliti lakukan terkait sikap atau tindakan orang tua yang masih kurang dalam memberikan imunisasi pada anaknya karena orang tua merasa bahwa memberikan imunisasi kepada anaknya bukan salah satu hal yang perlu dilakukan mengingat pengalaman ketika memberikan imunisasi pada anaknya hanya membuat mereka kewalahan mengurus anaknya yang demam dan rewel setelah di imunisasi. Serta alas an yang utama dalam sikap yang kurang dalam melengkapi imunisasi anak adalah kepercayaan terdahulu yang menganggap anak tidak perlu diberikan imunisasi seperti halnya nenek moyang mereka terdahulu. 
Hubungan dukungan keluarga terhadap ketidakpatuhan orang tua memberikan imunisasi

Berdasarkan hasil penelitian ini analisa bivariat yang menggunakan uji chi-square (Fisher exact) pada tabel 3 menunjukkan hasil $\mathrm{p}=0.01$ atau $\mathrm{p}=<0.05$ yang artinya $\mathrm{H} 0$ ditolak atau terdapat hubungan antara dukungan keluarga dengan ketidakpatuhan orang tua memberikan imunisasi. Dukungan keluarga yang rendah dalam hal ini terutama keluarga terdekat yaitu suami atau mertua dari responden juga mempengaruhi minat responden yang sangat rendah dalam memberikan imunisasi anaknya. Penelitian ini juga sejalan dengan penelitian yang dilakukan oleh Rahmawati bahwa bayi atau balita yang memiliki status imunisasi tidak lengkap dipengaruhi oleh kurangnya dukungan keluarga yang mana merupakan anggota keluarga terdekat ${ }^{6}$. Penelitian lain yang dilakukan oleh Saka, Tria \& Nana bahwa ada hubungan antara Dukungan Keluarga terhadap pemberian imunisasi MR pada Balita ${ }^{7}$.

\section{Hubungan jarak tempat pelayanan terhadap ketidakpatuhan memberikan imunisasi.}

Berdasarkan hasil penelitian ini analisa bivariat yang menggunakan uji chi-square ( Fisher exact ) pada tabel 3 didapatkan hasil nilai $\mathrm{p}=0.31$ atau $\mathrm{p}=>0.05$ yang artinya $\mathrm{H} 0$ diterima atau tidak terdapat hubungan antara jarak tempat pelayanan dengan ketidakpatuhan orang tua memberikan imunisasi. Hasil wawancara yang telah dilakukan bahwa ada yang menjadi faktor pencetus sehingga responden tidak memberikan imunisasi yaitu pada saat responden membawa anaknya ke tempat pelayanan di pertengahan jalan anak responden menangis dan rewel sehingga membuat responden kewalahan, serta jarak yag ditempuh tanpa menggunakan kendaraan merupakan factor pendorong sehingga responden tidak jadi memberikan imunisasi pada anaknya. Penelitian ini sejalan dengan penelitian yang dilakukan oleh Olwin, Dwi \& Lely tentang akses ke fasilitas kesehatan mengatakan bahwa tidak ada hubungan yang bermakna antara jarak dan waktu tempuh ke fasilitas kesehatan dengan status kelengkapan imunisasi baduta, tetapi ada factor yang lain seperti masih kurangnya masyarakat yang mengetahui adanya posyandu,poskesdes ataupun polindes ${ }^{8}$.

\section{Hubungan dukungan petugas kesehatan terhadap ketidakpatuhan orang tua memberikan imunisasi}

Berdasarkan hasil penelitian ini analisa bivariat yang menggunakan uji chi-square ( Fisher exact ) pada tabel 3 didapatkan hasil nilai $\mathrm{p}=0.23$ atau $\mathrm{p}=>0.05$ yang artinya $\mathrm{H} 0$ diterima atau tidak ada hubungan antara dukungan petugas kesehatan terhadap ketidakpatuhan orang tua memberikan imunisasi. Setelah mewancarai responden bahwa petugas kesehatan yang bertugas di tempat penelitian aktif dalam memberikan informasi serta memantau masyarakat yang tidak dating ke tempat pelayanan imunisasi dengan dating ke rumah-rumah warga. Ketidakpatuhan responden bukan berasal dari tidak adanya dukungan petugas kesehatan tetapi dari persepsi atau pola pikir responden yang membuat sikap acuh tak acuh terhadap pemberian imunisasi untuk anaknya. Sehingga meskipun petugas kesehatan ikut berperan aktif dalam memberikan informasi serta dukungan tetapi jika dari dalam diri responden enggan untuk melakukannya maka dukungan dari petugas kesehatan serta motivasi-motivasi yang diberikan oleh petugas tidak akan bias memberikan keputusan serta sikap yang positif terhadap penerimaan responden untuk memberikan imunisasi kepada anaknya. Penelitian ini sejalan dengan penelitian yang dilakukan oleh Olwin,Dwi \& Lely tentang sikap serta kehadiran petugas kesehatan tidak ada hubungannya dengan status kelengkapan 
imunisasi baduta karena sikap dan kehadiran petugas yang ramah dan selalu siap melayani bukan menjadi tolak ukur orang tua memberikan imunisasi tetapi ada factor lain seperti pemahaman yang masih minim tentang pentingnya imunisasi ${ }^{8}$.

\section{KESIMPULAN DAN SARAN}

Berdasarkan karakteristik responden di Wilayah Kerja Puskesmas Pemantu Desa Maninili Utara mayoritas responden memiliki usia dewasa awal ( 26-35 tahun ). Responden yang tidak bekerja menjadi mayoritas dari pada responden yang bekerja. Mayoritas pendidikan responden adalah responden yang memiliki pendidikan rendah ( SD dan SMP ).

Berdasarkan hasil analisis bivariate menggunakan uji chi-square ( Fisher exact ) didapatkan bahwa ada 3 variabel yang memiliki hubungan signifikan dengan ketidakpatuhan pemberian imunisasi lengkap yaitu pengetahuan, sikap dan dukungan keluarga. Sedangkan, terdapat dua variabel yang tidak memiliki hubungan signifikan dengan ketidakpatuhan pemberian imunisasi lengkap.

Diharapkan penelitian ini dapat menjadi referensi untuk penelitian selanjutnya. Bagi peneliti selanjutnya dapat menggunakan metode penelitian yang lain misalnya dengan menggunakan desain kualitatif atau dengan meniliti faktor lain yang dapat berpengaruh terhadap ketidakpatuhan pemberian imunisasi lengkap misalnya kepercayaan, kebudayaan atau dapat berupa minat responden dalam memberikan imunisasi lengkap, karena di Desa Maninili Utara masih banyak responden yang kurang minat dalam memberikan imunisasi serta kepercayaan mereka yang masih dipengaruhi oleh paham masa lalu.

\section{UCAPAN TERIMAKASIH}

Terimakasih kepada semua pihak yang telah membantu peneliti dalam menyelesaikan penelitian ini.

\section{DAFTAR PUSTAKA}

1. Kementerian Kesehatan RI. Buku Ajar Imunisasi.; 2015.

2. World Health Organization. Global Immunization. World Health Organization. Published 2019. Accessed April 10, 2020. https://www.kemdikbud.go.id/2019/04/pi d-2019-tingkatkan-cakupan-dan-mutuimunisasi-lengkap

3. Dinas Kesehatan Kota Palu. Profil Kesehatan Kota Palu.; 2017.

4. Putri RS. Faktor-Faktor Yang Mempengaruhi Kepatuhan Ibu Dalam Pemberian Imunisasi Dasar Pada Balita Di Dukuh Pilangbangau Desa Sepat Masaran Sragen Tahun 2016. Published online 2016.

5. Umaroh S. Hubungan antara pengetahuan dan sikap ibu dengan kelengkapan imunisasi dasar di wilayah kerja puskesmas kartasura kabupaten sukoharjo. Published online 2014.

6. Rahmawati AI, Umbul C. Faktor Yang Mempengaruhi Kelengkapan Imunisasi Dasar Di Kelurahan Krembangan Utara. $J$ Berk Epidemiol. 2014;2(1):59-70.

7. Pendit SA, Astika T, Supriyatna N. Analisis Pengaruh Dukungan Keluarga, dan Faktor Lainnya terhadap Pemberian Imunisasi MR pada Balita. J Keperawatan Silampari. 2019;3(1):322331. doi:10.31539/JKS.V3I1.848

8. Nainggolan O, Hapsari D, Indrawati L. Pengaruh Akses ke Fasilitas Kesehatan terhadap Kelengkapan Imunisasi Baduta (Analisis Riskesdas 2013). Media Penelit dan Pengemb Kesehat. 2016;26(1):15-28. doi:10.22435/MPK.V26I1.4900.15-28 